JOAL. (JOURNAL OF APPIIEI) LINGUISTICS ANI) LIT'BRA'TURE)

Vol. 4 No. 2, 2019

ISSN (print): 2502-7816; ISSN (online): 2503-524X

Available online at https:/ / ejournal.unib.ac.id/index.php/joall/index doi: http:/ / dx.doi.org/10.33369/joall.v4i2.7607

\title{
KINDS OF QUESTIONS MAKING EFL STUDENTS LEARN: STUDENTS' PERCEPTION
}

\author{
Mushoffan Prasetianto ${ }^{1}$ \\ Universitas Brawijaya ${ }^{1}$
}

\begin{abstract}
Corresponding email: m.prasetianto@ub.ac.id

Interactions in the classroom play an important role because learning occurs in the interactions between more knowledgeable person and less knowledgeable person. Interactions in the EFL classroom can be seen as a dialogic activity in which the lecturer raises questions to the students. This study attempted to uncover the types of questions which can make students learn. The participants of the study were the lecturer and students of Language Learning Assessment course. The data of this study were the students' perceptions on what kinds of questions make them learn and lecturer's verbal questions. The results of the study show that there are four kinds of questions raised by the lecturer, namely analogy, optional, convergent and divergent questions. From those kinds of questions, divergent questions can make students learn because those questions drive students to have a discussion in which students can interact each other.
\end{abstract}

Keywords: questions, make students learn, content course

\section{INTRODUCTION}

English is considered as a foreign language in Indonesia. It implies that the learners lack exposure of English in their environment. Newspapers, television and radio programs are rarely written or spoken in English. Thus, the language input that the learners get is only in the classroom. Whereas, in the classroom students learn the four skills and the time to learn English at school is limited, so teachers need to encourage students to learn English themselves outside the classroom.

However, a classroom is still the main place where teaching and learning occur. It consists of the interaction of students and a teacher. Sert and Walsh (2013) confirmed that classrooms are institutional settings where learning and teaching practices manifest themselves in interactions between students and teachers. In EFL classroom, the teacher acts as one of resources for the students since the students mostly get language input in the 
classroom. Renandya (2012) found that teachers have a resource role when the students need a help. Rohmah (2002) argued that the conversation and instructional exchanges between the teacher and the students are the best contribution of students' skill training. Students can learn by interacting with the teacher in the classroom. The teacher creates communicative situation to achieve the curricular objective (Mohtar and Yusoff, 1997).

Interactions in the classroom play an important role because learning occurs in the interactions between more knowledgeable person (the teachers) and less knowledgeable person (the learners). Sunggingwati and Nguyen (2013) suggested that interaction with more knowledgeable or capable others helps children construct an understanding of the construct. An interaction is the collaborative exchange of thoughts, feelings, or ideas between two or more people. Duron et al. (2006) found that questions can be used to stimulate interaction between the teacher and the learners. The teacher can interact with the learners by raising questions. Authentic questions should be raised to get thoughtful answer from the students (Zhang, 2008).

Interactions in the EFL classroom can be seen as a dialogic activity in which the teacher raises questions to the students. Sharpe (2008) concluded that a dialogic classroom is characterized by questions being posed. In line with Sharpe's study, McNeil (2012) found that dialogic approaches to teaching are questions that elicit students' thoughts, reasons, experiences and opinions. Teacher can construct students' knowledge through raising questions. Giving questions can shift classroom discourse toward more constructivist-based practice (Chin, 2007).

Questions are an essential part in teaching and learning process. Wong (2010) claimed that a question type is a key part of teacher's armoury. It can scaffold the thinking skill of the learners. Duron et al. (2006) figured out that teacher can establish what is already known and extend beyond that to develop ideas and understandings by raising questions. Caram and Davis (2005) confirmed that teacher-initiated question is simple, yet strong method for exploring idea and concept. It implies that questioning can promote the students understanding and thinking skills.

Questions play an essential role in students' learning. Questioning refers to the question asked by the teacher in the classroom. The teacher can help the learners to comprehend the text by giving question. In addition, teacher can monitor the learners' understanding through questioning. Chin (2007) suggests that questions can provide feedback for teacher about students' understanding. Boiser (2000) states that questioning is the easiest and the most immediate way for teacher to monitor the extent of comprehension in a classroom. 
The teacher should have a purpose in giving questions. The questions that are posted by the teacher can promote the comprehension when the teacher has a goal in his mind. Cotton (2001) confirmed that the purposes of teacher's questions are to develop interest and motivate students to become actively involved in lessons and develop critical thinking skills. Thus, the questions act as stairs which scaffold the students' comprehension.

Questions can be categorized into many types. Gabrielatos (1997) categorized into genuine question, authentic question and pedagogical question. Genuine question is the question which actually seeks information. Authentic question is question which teacher asks in order to get information he/she really needs. Pedagogical question is question which is asked as part of teaching and learning. Farahian and Rezaee (2012) classified questions into open/closed question, display and referential question, and yes/no question. Open question requires long answer, while closed question requires short answer. Display question refers to question given to the students in which the teacher already knows the answer. Referential question refers to question given to the students in which the teacher does not know the answer. Yes/no question requires yes or no answer. Richards and Lockhart (1996) categorized questions into procedural, convergent and divergent question. Procedural question refers to question which deal with classroom routine and procedure. Convergent question refers to question to encourage students to recall information. Divergent question refers to question which involve higher thinking level so that it encourages diverse responses of the students. Celce-Murcia and Larsen-Freeman (1999) categorized the forms of question into yes/no question, WH- question, and tag question. Yes/no question defines as question for which either yes or no is the expected answer. WH- question refers to question which is used to request specific information. Tag question is a short question form appended to statement.

The aforementioned types of questions are not the focus of the present study. The present study attempted to find the types of questions which can make students learn. It is essential to find which questions make students really learn. Learning means that the students follow up the teacher's question by reading references or discussing with others. Thus, a study which relates types of question with students' learning needs to be conducted. Making students learn means driving students to finish the task by either reading references or discussing with others. Students know how to direct and use their thought and action to finish task. Wood (1992) claims that questions may motivate, sustain and direct the thought process of the students.

Some previous studies related to questions raised by teacher have been conducted. In Australia, Sharpe's (2008) study found that modifying 
questioning or reformulate students' reasoning support their understanding of the process of historical inquiry. In Philippines, Delima's (2012) study found that students were encouraged to participate more in class discussion if teacher asks low-level question. In China, Yu's (2010) study suggested asking referential question to students to engage and interact in the classroom. Those previous studies were conducted in ESL context, while the present study will be conducted in EFL context in which there will be possibly different questions can be raised by the lecturer.

In Indonesia context, some previous studies related to question have been conducted. Sunggingwati and Nguyen (2013) conducted their study in Samarinda. They observed in three senior high schools. They found that teacher's questions follow the questions in the textbook. Another research was conducted by Rohmah (2002). Her study found that MAN (Madrasah Aliyah Negeri) teacher used more display questions and comprehension check. Kirana (2010) conducted her study in RSBI School. She observed how biology teacher gave questions. Her study found out that RSBI teacher has employed the questioning strategies and the application of those strategies was quite good. The previous studies aforementioned found the following ideas: the way the teacher generates question, the function of question for classroom interaction and the proportion of question type posed by teacher in the classroom. While, the present study find the types of questions which make EFL students learn.

The aforementioned previous studies did not relate question with students' learning. In fact, students' learning cannot be neglected because the objective of teaching is to make students learn. Thus, students' learning is important since it is related with the objective of teaching. Therefore, this study is conducted. This study investigates kinds of questions raised by the teacher which make the EFL learners learn. In this study, "making students learn" means driving the students to finish tasks by either reading references or discussing with others. It is expected to find out the questions which make the EFL students' learning.

\section{METHODS}

This study mainly used observation and retrospective protocol as the major research instruments. The research design was grounded theory. The researcher acted as non-participant observer in which the researcher just sat at the back of the classroom observing questions raised by the lecturer. The researcher observed the lecturer naturally. This study was designed to investigate questions raised by a lecturer which make students learn in the content course class.

The participants of the study were the lecturer and students of Language Learning Assessment course at one of university in Malang, 
Indonesia. There were 30 undergraduate students involved in the study and one lecturer. The students' characteristics were that students' English ability were relatively good because they were in the fifth semester. They comprehend the lecturer's questions well. It means that they did not misunderstand the lecturer's questions. There were 26 girls and 4 boys involved in the study. Language Learning Assessment course was chosen.

The lecturer who often raised questions was observed. A lecturer of Language Learning Assessment was observed because he posed many questions which met the purpose of this study. The researcher knew that lecturer posed many questions because he taught the researcher in undergraduate and graduate school. Thus, the researcher knew the way how the lecturer taught his students. The researcher used video recorder to observe him in the classroom. The observation was conducted until the questions raised varied. The researcher transcribed the recorded video. From the transcription, the researcher knew that the questions raised varied. The researcher stopped the observation when the questions varied. Then, the researcher made protocol instrument for the students.

The protocol consisted of two columns in which the questions raised by the lecturer and the other column was students' learning. The students wrote what they learned from the questions in protocol instrument. From the protocol, the researcher found the questions which made the students learn. The questions which made students learn were obtained from the highest frequency of the tally. It meant that many students wrote repeatedly the same question which makes them learn. Next, the researcher interviewed one student as a start and continues to other students until there was no new information obtained. Last, the researcher drew conclusion.

After the data were collected, the analysis was done through some steps. The first step was transcribing the video observation recording. After all data were transcribed, the researcher read through all data to get general sense. Then, based on the list of recorded questions raised by the lecturer, the researcher grouped the list of questions which had the same kind. Based on the researcher's interpretation and Richards and Lockhart (1996), the researcher categorized into four kinds of questions. From those kinds of questions, the researcher made retrospective protocol. The researcher collected the data to answer the first research question.

The second step was to identify the questions which make students learn. The researcher tallied the students' response from the protocol. The kinds of questions which had the most number of tallies were the questions which made students learn.

The third step was to interview the students. The researcher interviewed the students to know why the particular kind of question make students learn and what the students do to indicate they learn because of the 
question. The researcher interviewed outside the classroom. The researcher used semi-structure interview. The researcher stopped the interview when there was no more new information. The researcher collected the data from protocol and interview to answer the second research question.

The last step was to draw conclusion. The conclusion was taken when the students' opinion toward particular kind of questions from the retrospective protocol outnumbered than the others.

\section{FINDINGS}

\section{Kinds of Questions Raised by Lecturer}

The lecturer raises many questions during teaching and learning activities in his class. The observations are conducted in EFL classroom for three meetings. 160 questions were obtained during the researcher's observations. Those questions mostly use yes/no and $\mathrm{W} / \mathrm{H}$ questions. Researcher classifies those questions based on Richards and Lockhart (1996) and researcher's interpretation. Below is an example of analogy questions.

\section{Extract 1:}

$\mathrm{T}$ : What is test?

S: question Sir

$\mathrm{T}$ : questions?/ questions?/ what is it (pointing to mobile phone)?

S: mobile phone

$\mathrm{T}$ : what is mobile phone?/ one word

S: technology

T: technology?

S: tool

T: So, what is test?

S: instrument, method, tool, procedure

From the extract above, the lecturer asks the definition of a test. But, the students give wrong answers. Then, the lecturer modifies the question by asking "what is mobile phone?" The lecturer uses the real thing to prompt student's answer. The lecturer gives analogy between a test and a mobile phone. The following is another example of analogy questions.

\section{Extract 2}

T: okay/ do you have motor cycle?

S: yes

T: what is inside your motor cycle?

S: engine

$\mathrm{T}$ : begin with $\mathrm{O} /$ followed by I

S: oil

T: can you see the oil of motorcycle?

S: no

$\mathrm{T}$ : how can you see the oil of motorcycle?

S: make it out

T: how? (showing a gesture of opening screw)/ what is the name? namanya apa itu?

S: tap 
T: yes/ to tap// what is actually the function of test?

S: to tap

T: in test, what to tap for?

S: knowledge, ability, competence

From extract 2, the lecturer asks about the function of the test. Since the students' competence exists in mind which we cannot see it directly, the lecturer tries to ask real things to relate to the concept. The lecturer asks "what is inside in your motorcycle?" and "how can you see the oil of motorcycle?" Those questions can bring real things to make student understand the concept easier.

The lecturer uses analogy to explain the concept to students. Thus, questions such as (what is mobile phone?; what is marker?; what is the function of marker?; what is inside your motor cycle?; Do you pray?) can be categorized into analogy questions. Analogy questions are the questions which use other things as similarity to make students understand a certain concept more easily. There are 15 analogy questions during observations. The following is examples of optional questions.

Extract 3:

$\mathrm{T}$ : is language aptitude test standardized test or it is made by a teacher? Is it made by an expert or teacher?

S: expert

Extract 4:

T: my question what is theory an expert can be used to design language aptitude test? Is it theory about language in general or do you refer to curriculum or what?/ which one?

S: theory about language

From the extracts above, the lecturer asks "is language aptitude test standardized test or it is made by a teacher?" and "Is it theory about language in general or do you refer to curriculum or what?" The lecturer asks the students by providing options. It is indicated by "or". Thus, the students just choose from the options provided. Those questions can be categorized into optional questions.

Optional questions are the questions which use "or" and give choices for the students to choose. The questions which comprise optional categories are "what kind of behavior? Physical or verbal?, is language aptitude test is standardized test or it is made by a teacher?, Is it theory about language in general or do you refer to curriculum or what?". There are 6 optional questions obtained during observations.

Extract 5:

$\mathrm{T}$ : where is the position of competence?/ where is the location of ability?/ where is the position of knowledge?

S: in mind

$\mathrm{T}$ : something which exist in your mind, do you think you can see it?

S: no 
From the extract above, the lecturer asks Yes/No questions "do you think you can see it?" This type of questions does not give opportunity for students to give wide responses, instead, the students just answer "No".

Extract 6:

T: now have a look at norm side, legal document/ so basically thay are in the form of something which are physical/ kira-kira apa ya? Begin with $\mathrm{K} /$ what is it?

S: kurikulum

$\mathrm{T}$ : is it document? Is it legal?

S: yes

$\mathrm{T}$ : what you mean by competence in terms of norm here is kurikulum/ what kind of kurikulum are you using now?

S: K-13

The extract above shows that the lecturer asks questions which recall the student's background knowledge. The lecturer poses question "what kind of curriculum are you using now?" This question tries to solicit student's background knowledge. Those questions can be categorized as convergent questions because the lecturer already knows the answer, the lecturer just want to know students' knowledge. Convergent questions are the questions to recall background knowledge of the students. It sometimes needs short responses. Questions such as: something which exist in your mind, do you think you can see it?, what is instruction?, what kind of curriculum are you using now?, how many KI (kompetensi inti) do you have?, what is the standard process? are included into the convergent category. There are 131 convergent questions obtained during observations.

\section{Extract 7}

T: what is one of test based on purpose?

S: proficiency test, aptitude test, diagnosis test, placement test, achievement test, test for research, selection test

T: excellent/ those are among others test based on function, based on objective//okay now look at your note again, there are seven function we can identify the purpose of making test/ please order this types of test logically according to logical order, what are the logical order of test based on purpose?

S: (students discus each other)

T: finish?

S: yes

T: who has found the correct order? Ya Salim

S: the first is selection, placement, research, diagnosis, aptitude, proficiency, and the last is achievement

The extract above shows that the lecturer poses question "what is the logical order of test based on purpose?" This question needs student's opinion. It is possible that students give wide responses instead of just yes/no answer or short responses. This kind of questions need long responses from students and prompt student's thinking skill to higher level because the students should analyze first before they give responses. This kind of questions can be categorized into the divergent questions. 
Divergent questions are questions which solicit wide responses of students. It sometimes elicits long responses from students. Questions such as: what do you want to test actually?, what is the material of the test?, what is competence?, competence consist of three component. What are they?, what are the logical order of test based on purpose? are included into the divergent category. There are 8 divergent questions.

During the observation, the lecturer raised 160 questions. Those questions can be categorized into four categories. Analogy and optional questions are terminology from the researcher. While, convergent and divergent questions are terminology from Richards and Lockhart (1996).

\section{Questions Making Students Learn}

The questions which make students learn are obtained from protocol. From the result shows that 5 out of 30 students respond that analogy questions can scaffold their understanding toward the lesson. Seven students respond that optional questions could drive them to read references in internet or library. No single student responds that convergent questions make them learn. 13 students respond that divergent questions make students discuss with their peers. Other 5 students respond that divergent questions make them summarize the lesson. Thus, divergent questions make students learn because most of students respond divergent questions. Through divergent questions, students discuss with their peers.

The result of interviews show that questions raised by the lecturer is important. From the kinds of questions raised by the lecturer, the interviewees think that divergent questions make them learn better because it can promote their critical thinking. The interviewees said that "divergent questions consist of some questions which can stimulate my critical thinking". Furthermore, the interviewees said that divergent questions "can build bridge between their knowledge through questions raised by lecturer." It means that the knowledge gap between the teacher and students can be bridged through divergent questions. In addition, divergent questions give opportunity for students to respond longer as the interviewees said "in divergent questions we need long answers". Below is an example of the interviews

\section{Extract 8}

I: from those questions raised by lecturer, which one do you think make you learn?

S: from those question, I think I will learn better in divergent question

I: why?

S: because divergent question consist of some questions which can stimulate my critical thinking so that I can learn deeper and deeper about the subject 


\section{Extract 9}

I: so far your lecturer ask many questions. And from those question which one make you learn?

S: divergent

I: why?

$S$ : because from the divergent, the lecturer let the student think critically. The lecturer doesn't know what will the student answer. From the divergent question, student can build bridge between their knowledge through question raised by lecturer. And force students to think critically. Divergent question is more challenging.

The interviewees also said that they would discuss with their friends who sits next to them when the lecturer gives divergent questions. The interviewees said "share our opinion with my friends through discussion." The students share their opinion in the discussion when the lecturer raises divergent questions. In the discussion, students who are less capable in comprehending lecturer's questions ask help from other friends who are capable. This interaction between less capable students and more capable students promote students' understanding. It indicates that the divergent questions make the students learn by discussion.

\section{DISCUSSION}

\section{Kinds of Questions Raised by Lecturer}

The lecturer asks 160 questions during teaching and learning. The questions invite the students' response. The lecturer raises questions to encourage students' responses and avoid spoon feeding teaching. The lecturer raises questions and lets students find the answers themselves.

In this study, the lecturer spends most of his teaching by giving questions. The questions which the lecturer raised vary. There are four categories found in this study: analogy, optional, convergent and divergent questions. There are 15 analogy questions, 6 optional questions, 131 convergent questions and 8 divergent questions. The lecturer uses those categories based on situation or student's responses. At the beginning of the lesson, the lecturer always asks questions. When the students cannot answer the questions, the lecturer modifies or changes his questions. Toni and Parse (2013) support that students' comprehension and language proficiency determine teacher's questions.

Analogy questions can be used to introduce concept what the topic of the lesson. In this study, the lecturer asks a question "what is the function of a test?" The students cannot answer. Then, the lecturer uses an analogy question to deliver the concept by asking "how make oil out of motorcycle?" The lecturer visualizes the function of a test with oil in the motorcycle. It is important to visualize the real things with the concept of the lesson. Harrison and Treagust (2006) suggest that meaningful learning in 
introducing new concept can happen when the students connect the newly taught concept with what they already know. Thus, analogy questions can build link between things which students know and the concept of the lesson.

Optional questions provide students with options. Optional questions use "or" which indicates the students just chooses from the provided options. This kind of questions includes lower level of thinking because students just recall the knowledge. This kind of questions also has function as helper for students. In line with Rohmah's (2002) study found that an alternative question is used to help student if the students find difficulty in answering the question.

Convergent questions also include lower level of thinking because it recalls students' knowledge and needs short responses from the students. Lee and Kinzie's (2012) study found that lower level questions are frequently used to recall students' knowledge. Lecturer frequently uses convergent questions at beginning of the lesson. It functions as stimulation of students' background knowledge. According to Ho's (2005) study found that there are 3 levels of questions: level 1, level 2 and level 3. Level 1 is the questions that the teachers already knows the answers and have limited responses. Level 2 is the questions that are designed to "gauge language proficiency". Level 3 is the questions that are "purely exploratory" and the teacher genuinely want to know the answers. Convergent questions include level 1 because the questions have limited responses and have one correct answer. The lecturer uses convergent questions to test student's understanding about the subject.

Divergent questions give opportunity for students to respond longer. It provides students to promote higher level of thinking because students should think first how to respond the questions. Divergent questions invite different responses from students. In line with Kayaoglu's (2013) study found that divergent questions invite diverse responses from students and require higher level of thinking. Divergent questions includes in level 3 (Ho, 2005). Students must be able to recall some information from memory, but must apply that knowledge and other knowledge to explain, or analyze a topic. Moreover, the students can explore and justify their answers if it is necessary.

\section{Questions Making Students Learn}

Students attend a class with purpose. They attend the class to learn, from knowing nothing to knowing something. Students have to do something to learn. One of which is interaction, interaction between students and students or lecturer and students. Schwab (2011) supports that learning is not an 
individual process but more likely participation which means learning cannot happen individually but learning happens in interaction.

Learning is collaborative and co-constructed between lecturer and students. Learning can happen in the classroom in which teacher's role is as facilitator (Sharpe, 2008). Lecturer is not knowledge transmitter. Lecturer should interact and invite students' participation to scaffold students' thinking skill from lower to higher order. Student-lecturer interactions can be generated through questions. Thus, lecturer should ask questions which make students learn.

Lecturer should know questions which can drive students to read references more or have discussion. Students can learn from their peer through discussion. Discussion is used by teacher to affect cognitive potential (Zhang, 2008). Students can share ideas and opinion in discussion. Students whose ability is higher can tell others whose ability is lower. This student-student interaction can promote learning.

The result of this study shows that divergent questions can make students learn. From the interviews, students respond that this kind of questions can drive them to discuss with someone who sits next to them. Hill and Flynn (2008) believe that teacher should provide students "cognitively rich experience" through discussion. Discussion can promote students' cognitive to critical thinking skill. In line with Self-Regulated Learning theory (Zimmerman, 2008), students personally direct form of learning such as seeking help from peers. Discussion can be a way for students to find a help from their peers.

Divergent questions can make students learn by having a discussion. In discussion, students interact with each other. A student interacts with other students whose ability is higher. Students can share knowledge and opinion during discussion. Moreover, students are self-regulated learners if they see themselves as agent of their own behavior (Montalvo and Torres, 2004). It means that students control their own behavior, one of which is discussion, to reach academic goal.

For classroom practitioner/teacher, he/she should use questions in certain situation such as stimulating new topic, checking students' understanding and promoting students' participation in the classroom. In stimulating topic, practitioner should use analogy questions which mean relating the topic with something around students' daily life. In checking students' understanding, practitioner should use convergent and optional questions to monitor students' understanding toward the lesson. Practitioner should use divergent questions to promote students participation because divergent drive students to discuss with their peers.

The limitation of the study is that this study used students' perception. Students' perception is used because it is easier than finding the 
facts of students' learning. It is difficult to monitor the students' achievement. Therefore, students' perception is used in this study considering the time of data collection and difficulty of following informants' learning. Since there is no empirical research to find the effectiveness of the questions toward students' achievement. Therefore, experimental research is needed to conduct for further researcher.

\section{CONCLUSION AND SUGGESTION}

Lecturers can raise questions to engage students' interaction in the classroom. The interaction can help students' learning. In the interaction, students can learn from their peer through discussion. Lecturers can prompt students' discussion via their questions. From the findings, there are four kinds of questions lecturers can raise. They are analogy, optional, convergent and divergent questions. Based on students' perception, divergent questions make students learn via discussion. Lecturers can make students learn if the lecturers raise divergent questions. Divergent questions provide discussions within students. In a nutshell, lecturers raise divergent questions if they want to make students learn because divergent questions can direct students to discuss.

\section{REFERENCES}

Boiser, D. C. 2000. Strategies for Teaching: A Modular Approach. Manila: Rex.

Caram, C.A. and Davis, P. B. 2005. Inviting Student Engagement with Questioning. Kappa Delta Pi Record: 18-23.

Celce-Murcia, M. and Larsen-Freeman, D. 1999. The Grammar Book: An ESL/EFL Teacher's Course $2^{\text {nd }}$ Edition. _USA: Heinle and Heinle.

Chin, C. 2007. Teacher Questioning in Science Classrooms: Approaches that Stimulate Productive Thinking. Journal of Research in Science Teaching 44 (6): 815-843.

Cotton, K. 2001. Classroom Questioning. School Improvement Research Series. http://educationnorthwest.org/webfm_send/569. Accessed January 12 2014.

Delima, E. M. 2012. A Reticent Student in the Classroom: A Consequence of the Art of Questioning. Asian EFL Journal. Professional Teaching Article: Conference Issue 60 (2): 50-69.

Duron, R., Limbach, B. and Waugh, W. 2006. Critical Thinking Framework for Any Discipline. International Journal of Teaching and Learning in Higher Education 17 (2): 160-166.

Farahian, M. and Rezaee, M. 2012. A Case Study of An EFL Teacher's Type of Questions: An Investigation into Classroom Interaction. Procedia Social and Behavioral Sciences 47: 161 - 167. 
Gabrielatos, C. 1997. A Question of Function: Teacher Questions in the EFL Classroom. Paper given at 18th Annual TESOL Greece Convention, National Bank of Greece Training Centre, Glyfada, Greece, 12-13 April 1997. http://www.gabrielatos.com/TQ.pdf. Accessed December 15 2013.

Harrison, A.G. and Treagust, D.F. 2006. Teaching and Learning With Analogy: Friend Or Foe. In Aubusson, P.J., Harrison, A.G. and Ritchie, S.M. (eds.) Metaphor and Analogy in Science Education (pp. 11-24). Dordrecht: Springer.

Hill, J. D. and Flynn, K. 2008. Asking the Right Questions. National Staff Development Council 29 (1): 46-52.

Ho, D. G. E. 2005. Why Do Teachers Ask the Questions They Ask? RELC Journal 36(3): 297-310.

Kayaoglu, M. N. 2013. Case Study into the Classroom Questions by a Native Speaker and a Non-Native Speaker Teacher in EFL Classes. The Asian EFL Journal Professional Teaching Article 69: 4-31.

Kirana, A. M. 2010. Questioning Strategies Employed By A Biology Teacher In The RSBI Program of SMPN 5 Malang. Unpublished Thesis. Malang: State University of Malang.

Lee, Y. and Kinzie, M.B. 2012. Teacher Question and Student Response With Regard to Cognition and Language Use. Instructional Science 40: 857-874

McNeil, L. 2012. Using Talk to Scaffold Referential Questions for English Language Learners. Teaching and Teacher Education 28: 396-404.

Mohtar, T.M.T. and Yusoff, M. 1997. Sustaining Student Engagement in Classroom Discourse. The Language Teacher Issue 21(9). http://jaltpublications.org/tlt/articles/2199-sustaining-student-engagementclassroom-discourse. Accessed January 102014.

Montalvo, F. T. and Torres, M. C. G. 2004. Self-Regulated Learning: Current and Future Directions. Electronic Journal of Research in Educational Psychology 2 (1): 1-34.

Renandya, W.A., 2012. Teacher Roles in EIL. The European Journal of Applied Linguistics and TEFL 2: 65-80.

Richards, J. and Lockhart, C. 1996. Reflective Teaching in Second Language Classroom. New York: Cambridge University Press.

Rohmah, Z. 2002. Teacher's Questions in Reading Classes. TEFLIN Journal 13 (2): 163-174.

Schwab, G. 2011. From Dialogue to Multilogue: A Different View on Participation In The English Foreign-Language Classroom. Classroom Discourse 2(1): 3-19.

Sert and Walsh. 2013. The Interactional Management of Claims of Insufficient Knowledge in English Language Classrooms. Language and Education 27 (6): 542-565. 
Sharpe, T. 2008. How Can Teacher Talk Support Learning?. Linguistics and Education 19: 132-148.

Sunggingwati, D. and Nguyen, H. T. M. 2013. Teachers' Questioning in Reading Lessons: A Case Study in Indonesia. Electronic Journal of Foreign Language Teaching 10 (1): 80-95.

Toni, A. and Parse, F. 2013. The Status of Teacher's Questions and Students' Responses: The Case of an EFL Class. Journal of Language Teaching and Research 4 (3): 564-569

Wong, R. 2010. Classifying Teacher Questions In EFL Classrooms: Question Types and Their Proper Use. TESOL in Context 20 (1): 37-57.

Wood, D. 1992. Teaching Talk: How Modes of Teacher Talk Affect Pupil Participation, in Norman, K. (ed.) Thinking Voices: the Work of the National Oracy Project (pp. 203-214). London: Hodder \& Stoughton.

Yu, W. 2010. An Analysis of College English Classroom Questioning. Journal of Language Teaching and Research 1 (2): 136-144.

Zhang, Y. 2008. Classroom Discourse and Students Learning. Asian Social Science 4 (9): 80-83.

Zimmerman, B. J. 2008. Investigating Self-Regulation and Motivation: Historical Background, Methodological Developments, and Future Prospects. American Educational Research Journal 45 (1): 166-183. 